\title{
Preliminary results from Brazil's first recovery housing program
}

\author{
Dados preliminares do primeiro programa de moradia monitorada no Brasil
}

\author{
Dhione Almeida do Carmo, ${ }^{1,2}$ Sonia Maria Motta Palma, ${ }^{1,2}$ Ariadne Ribeiro, ${ }^{1,2}$ Alisson Paulino Trevizol, ${ }^{2}$ \\ Elisa Brietzke, ${ }^{1}$ Renata Rigacci Abdalla, ${ }^{1,2}$ Ana Leonor Sala Alonso, ${ }^{2}$ Claudio Jerônimo da Silva, ${ }^{1,2}$ \\ Quirino Cordeiro, ${ }^{1,2}$ Ronaldo Laranjeira, ${ }^{1,2}$ Marcelo Ribeiro ${ }^{1,2}$
}

\begin{abstract}
Introduction: The recovery housing $(\mathrm{RH})$ program was initiated in São Paulo with the objective of providing treatment for substance use disorders and addressing users' housing and employment problems. The purpose of this study was to describe the model based on its first 11 months of operation, it was launched in June 2016 in Brazil.

Method: We carried out a retrospective analysis of the records of all subjects treated in the RH of the Restart Program (Programa Recomeço) since its creation, from June 2016 to May 2017.

Results: Sixty-nine subjects were included. Thirty-five (51\%) remained in the household until the end of treatment or were reinserted in society. Thirty-four (49\%) presented recurrence during their stay, of which $16(47 \%)$ volunteered for treatment in a therapeutic community or psychiatric hospital, 8 (23.5\%) chose to continue with outpatient treatment only, $6(17.7 \%)$ returned to their families and continued to receive outpatient treatment, and $4(11.8 \%)$ discontinued the treatment. Of the 35 subjects who completed the RH program, 28 (80\%) were in employment and $7(20 \%)$ received governmental support for permanent disability on medical or psychiatric grounds.

Conclusion: $\mathrm{RH}$ can be an important component of integrated care and is used in several countries. Although controversial, the use of urine tests to control relapse seems to have a positive impact on adherence to treatment and maintenance of abstinence. These preliminary findings corroborate, with clear limitations, the evidence available in the literature showing that $\mathrm{RH}$ programs are effective for the treatment of addictions.

Keywords: Crack cocaine, cocaine, substance-related disorders, substance abuse, substance abuse treatment centers, recovery housing, sober house, addictions.
\end{abstract}

\section{Resumo}

Introdução: O Programa Moradia Monitorada (MM) foi iniciado em São Paulo com o objetivo de prover tratamento para transotrnos de uso de substâncias e problemas relacionados a moradia e emprego. O objetivo do presente estudo foi descrever o modelo com base nos primeiros 11 meses de operação (o programa foi lançado em junho de 2016 no Brasil).

Métodos: Realizamos um estudo retrospectivo utilizando os registros de todos os indivíduos tratados no MM do Programa Recomeço desde a sua criação.

Resultados: Sessenta e nove indivíduos foram incluídos. Trinta e cinco $(51 \%)$ permaneceram no tratamento até o fim ou foram reinseridos socialmente com sucesso. Trinta e quatro sujeitos (49\%) apresentaram recidiva durante a permanência. Destes, 16 (47\%) se voluntariaram para tratamento em comunidades terapêuticas ou hospitais psiquiátricos, $8(23,5 \%)$ escolheram permanecer apenas no tratamento ambulatorial, $6(17.7 \%)$ retornaram para suas famílias e continuaram o tratamento em uma unidade ambulatorial próxima ao domicílio, e 4 (11.8\%) descontinuaram o tratamento. Dos 35 pacientes que completaram o tratamento, 28 (80\%) estavam empregados em serviço regular e 7 (20\%) recebiam aposentadoria por questões clínicas e/ou psiquiátricas.

Conclusão: $\mathrm{O}$ modelo MM pode ser um componente importante na via de cuidados integrados e é utilizado em vários países. Apesar de controverso, o uso de análise de urina para vigilância da recidiva e da recorrência parece ter um impacto positivo na adesão ao tratamento e na manutenção da abstinência. Nossos achados preliminares corroboram, com claras limitações, os resultados reportados previamente na literatura, de que os programas de MM são efetivos no tratamento da dependência química.

Descritores: Crack, cocaína, transtornos relacionados ao uso de substâncias, abuso de substâncias, centros de tratamento de abuso de substâncias, dependência química, moradia monitorada.

\footnotetext{
${ }^{1}$ Departamento de Psiquiatria, Universidade Federal de São Paulo, São Paulo, SP, Brazil. ${ }^{2}$ Centro de Referência de Álcool, Tabaco e Outras Drogas (CRATOD), Secretaria Estadual de Saúde, São Paulo, SP, Brazil.

Submitted Jul 13 2017, accepted for publication Jan 242018.

Suggested citation: do Carmo DA, Palma SMM, Ribeiro A, Trevizol AP, Brietzke E, Abdalla RR, et al. Preliminary results from Brazil's first recovery housing program. Trends Psychiatry Psychother. 2018;40(4):285-291. http://dx.doi.org/10.1590/2237-6089-2017-0084
} 


\section{Introduction}

São Paulo is a cosmopolitan megalopolis of 12 million inhabitants and has the biggest population of crack cocaine users in Brazil. ${ }^{1}$ This population is extremely vulnerable and at high risk of serious health and social issues, lack of social support, unemployment and homelessness. The main open-air concentration of drug users is known as "Cracolândia,"1 and drugs are used and traded non-stop in this area. In May 2013, the São Paulo state government responded to this growing public health and social security issue by launching the Restart Program (Programa Recomeço), under Decree 59164 , of $09 / 05 / 2013$, with the objective of providing treatment for substance use disorders and addressing the users' housing and employment problems. The components of the program include recovery housing $(\mathrm{RH})$, established in June 2016 as an element of postdetoxification rehabilitation. The $\mathrm{RH}$ program is based on multiple similar programs in Europe and North America that have demonstrated robust positive effects, such as improved adherence to treatment and maintenance of abstinence, longer time to relapse and higher rates of employment. ${ }^{2}$

Residential rehabilitation is an important element of integrated care pathways. ${ }^{3}$ Residential rehabilitation programs provide accommodation in a drug-free environment and a range of structured interventions to address drug and alcohol misuse, including abstinenceoriented interventions. ${ }^{4}$ Illicit drugs are not allowed in residential rehabilitation and drug tests may be used to detect non-compliance with this requirement as well as other measures to ensure that residents do not bring drugs into the accommodation. ${ }^{4}$ Studies have shown a reduction in the use of illicit drugs in individuals who enter residential rehabilitation. Although treatment discontinuation was common, one study found that individuals who completed a housing program had better outcomes than those undergoing standard ambulatory treatments in terms of drug use, crime, employability and social functioning. ${ }^{5}$

The main features of our $\mathrm{RH}$ program are multiprofessional case management, a drug-free environment, monitoring of drug use through urine analysis to encourage abstinence, and pharmacological and psychotherapeutic treatment. Its main objective is to reintegrate subjects into society by helping them to enter employment, achieve autonomy, remain abstinent and adhere to treatment. The purpose of this study was to describe the model based on its first 11 months of operation, and the results obtained so far.

\section{Methods}

We performed a cross-sectional retrospective analysis of the records of all subjects $(n=69)$ treated in the RH of the Restart Program since its creation from June 2016 to May 2017. Patient records consisted of multidisciplinary and medical interviews.

Assessments were performed through an interview with a structured questionnaire covering sociodemographic characteristics, substance use patterns, and social vulnerability, conducted by a trained social worker. The questionnaire was applied to all subjects during admission to the service. All patients were weekly followed by the same social worker, who monitored social reintegration and also collected information from all patients' records at the center for psychosocial care (Centro de Atenção Psicossocial [CAPS]) of the Referral Center for Alcohol, Tobacco and Other Drugs (Centro de Referência de Álcool, Tabaco e Outras Drogas [CRATOD]), where all patients were treated.

The local ethics committee approved this study (CAAE 68624617.5.0000.5505). Data are reported according to the Strengthening the Reporting of Observational Studies in Epidemiology (STROBE) statement. All data are stored in the Open Science Framework data repository and will be made available upon request.

\section{The RH program}

The RH target group consists of subjects who are discharged from hospitals and are followed by CAPSs. All data were extracted independently by two researchers (DAC and SMMP), and any discrepancy was resolved by discussion. The following data were extracted: gender, age, education, work status, housing situation, substances used, time to relapse and recurrence, social reinsertion and treatment adherence. Statistics were descriptive only.

The RH assessed is located in a three-story building in Cracolândia, São Paulo's main area for crack cocaine use. It has 36 beds ( 24 for males), three laundries, three meeting rooms, a kitchen and a fitness center.

In order to be admitted, subjects are evaluated by a team of trained psychiatrists, psychologists and social assistants from the outpatient unit. Urine tests are performed twice in a period of 10 days prior to admission. Only subjects with negative results on the drug tests are admitted to the $\mathrm{RH}$ program. Candidates who return a positive test in the admission period are referred to a public hostel and should be offered another opportunity to join the program after 90 days. 


\section{Screening tests}

Urine analysis kits manufactured by ABON Biopharm (MultiDrug Line Device) are used. Testing is carried out by a trained nurse. During treatment at the $\mathrm{RH}$ program, urine tests are performed every 5 days and twice a week in case of suspected relapse. When positive results are found, an individual recurrence prevention protocol is carried out.

Recurrence is determined when three consecutive tests result positive over a period of 15 days. Relapse is differentiated from recurrence based on the subsequent discontinuation of drug use, demonstrated by one positive test followed by a negative test.

\section{Statistical analysis}

Statistical analysis was performed using STATA 13. All estimates of prevalence were made using the appropriate STATA command to generate robust standard errors. Categorical variables were analyzed using Fisher's exact test. As the data were skewed, group differences were analyzed with non-parametric tests (Wilcoxon's rank sum test and the Kruskal-Wallis test for more than two groups).

\section{Results}

Over the 11-month period, 69 residents entered the $\mathrm{RH}$ program. Demographic and clinical characteristics of RH residents from January to June 2017 are presented in Table 1. In gender comparison, the analyses show statistically significant differences for age, living on the street, exchanging sex for drugs, asking for help, and receiving government benefit.

Table 1 - Demographic and clinical characteristics of the subjects, divided by gender, treated at the recovery housing from January to June 2017

\begin{tabular}{|c|c|c|c|c|}
\hline & Total $(n=70)$ & Male $(n=53)$ & Female $(n=17)$ & $\mathbf{p}$ \\
\hline \multicolumn{5}{|l|}{ Sociodemographic characteristics } \\
\hline Gender & & $53(75.7)$ & $17(24.3)$ & $0.01 *$ \\
\hline Age, mean (SD) & & $42.9(9.63)$ & $37.41(8.87)$ & $0.01^{+}$ \\
\hline Education $(n=70)$ & & & & $0.56 *$ \\
\hline Illiterate & $33(47.2)$ & $23(32.8)$ & $10(14.3)$ & \\
\hline Incomplete elementary school & $13(18.5)$ & $10(14.3)$ & $3(4.3)$ & \\
\hline Incomplete high school & $7(10)$ & $5(7.1)$ & $2(2.8)$ & \\
\hline High school & $17(24.3)$ & $15(21.5)$ & $2(2.8)$ & \\
\hline Housing: 1st time homeless $(n=70)$ & & & & $0.001 *$ \\
\hline No & $58(82.8)$ & $49(70)$ & $9(12.8)$ & \\
\hline Yes & $12(17.2)$ & $4(5.7)$ & $8(11.4)$ & \\
\hline Employment $(n=70)$ & & & & $1.0 *$ \\
\hline Non-employed & $68(97.1)$ & $51(96.2)$ & $17(24.3)$ & \\
\hline Origin $(n=70)$ & & & & $0,82 *$ \\
\hline Sao Paulo City & $21(30)$ & $17(24.3)$ & $4(5.7)$ & \\
\hline State of São Paulo & $18(25.7)$ & $13(18.6)$ & $5(7.1)$ & \\
\hline Other states & $31(44.3)$ & $23(32.8)$ & $8(11.4)$ & \\
\hline \multicolumn{5}{|l|}{ Clinical characteristics and risk behaviors } \\
\hline Psychotic symptoms $(n=70)$ & & & & $0.16 *$ \\
\hline No & $35(50)$ & $29(41.4)$ & $6(8.6)$ & \\
\hline Under the effect of drug & $10(14.3)$ & $8(11.4)$ & $2(2.9)$ & \\
\hline No drug effect & $7(10)$ & $3(4.3)$ & $4(5.7)$ & \\
\hline Being intoxicated or not & $18(25.7)$ & $13(18.6)$ & $5(7.1)$ & \\
\hline Comorbidities $(n=70)$ & & & & $1.0 *$ \\
\hline No & $55(78.6)$ & $41(58.6)$ & $14(20)$ & \\
\hline Yes & $15(21.4)$ & $12(17.1)$ & $3(4.3)$ & \\
\hline Street violence $(n=70)$ & & & & $0.64 *$ \\
\hline No & $41(58.6)$ & $29(41.4)$ & $12(17.1)$ & \\
\hline Yes, from other non-drug users & $4(5.7)$ & $4(5.7)$ & 0 & \\
\hline Yes, from other drug users & $22(31.4)$ & $17(24.3)$ & $5(7.1)$ & \\
\hline Yes, from the police & $3(4.3)$ & $3(4.3)$ & 0 & \\
\hline Sexual abuse on the street $(n=70)$ & & & & $0,12 *$ \\
\hline No & $56(80)$ & $43(61.4)$ & $13(18.6)$ & \\
\hline Yes, from other drug users & $12(17.2)$ & $10(14.3)$ & $2(2.9)$ & \\
\hline Yes, from other drug users of the opposite gender & $1(1.4)$ & 0 & $1(1.4)$ & \\
\hline Yes, from other drug users of the same gender & $1(1.4)$ & 0 & $1(1.4)$ & \\
\hline
\end{tabular}


Table 1 - (cont.)

\begin{tabular}{|c|c|c|c|c|}
\hline & Total $(n=70)$ & Male $(n=53)$ & Female $(n=17)$ & $\mathbf{p}$ \\
\hline Exchanging sex for drugs $(n=70)$ & & & & 0.02* \\
\hline No & $53(75.7)$ & $44(62.8)$ & $9(12.8)$ & \\
\hline Yes & $17(14.3)$ & $9(12.9)$ & $8(11.4)$ & \\
\hline Condom use & & & & $0.32 *$ \\
\hline Never & $30(42.3)$ & $23(32.8)$ & $7(10)$ & \\
\hline Eventually & $15(21.4)$ & $11(15.7)$ & $4(5.7)$ & \\
\hline Always & $22(31.4)$ & $18(25.7)$ & $4(5.7)$ & \\
\hline Does not remember & $3(4.3)$ & $1(1.4)$ & $2(2.8)$ & \\
\hline \multicolumn{5}{|l|}{ Family support } \\
\hline Contact with family $(n=70)$ & & & & $1.0^{*}$ \\
\hline No & $39(55.7)$ & $29(41.4)$ & $10(14.3)$ & \\
\hline 5 times a week & $31(44.3)$ & $24(34.3)$ & $7(10)$ & \\
\hline Sought help in the last year $(n=70)$ & & & & $0.04 *$ \\
\hline Health professionals & $66(94.3)$ & $52(74.3)$ & $14(20)$ & \\
\hline Family & $4(5.7)$ & $1(1.4)$ & $3(4.3)$ & \\
\hline Children $(n=70)$ & & & & $0.58 *$ \\
\hline No & $32(45.7)$ & $23(32.8)$ & $9(12.8)$ & \\
\hline Yes & $38(54.3)$ & $30(42.8)$ & $8(11.4)$ & \\
\hline Loss of child custody $(n=37)$ & & $(n=29)$ & $(n=8)$ & $0.59 *$ \\
\hline No & $31(83.8)$ & $25(67.6)$ & $6(16.2)$ & \\
\hline Yes & $6(16.2)$ & $4(10.8)$ & $2(5.4)$ & \\
\hline Caregiver of the children $(n=37)$ & $(n=37)$ & $(n=29)$ & $(n=8)$ & $0.9 *$ \\
\hline Subject & $1(2.7)$ & $0(0)$ & $1(2.7)$ & \\
\hline Other parent & $30(81)$ & $25(67.6)$ & $5(13.5)$ & \\
\hline Grandparents & $2(5.4)$ & $2(5.4)$ & $0(0)$ & \\
\hline Separated in the family & $3(8.1)$ & $2(5.4)$ & $1(2.7)$ & \\
\hline Does not know & $1(2.7)$ & 0() & $1(2.7)$ & \\
\hline Family participating in treatment $(n=70)$ & & & & $1 *$ \\
\hline No & $59(84.3)$ & $45(64.3)$ & $14(20)$ & \\
\hline Yes & $11(15.7)$ & $8(11.4)$ & $3(4.3)$ & \\
\hline \multicolumn{5}{|l|}{ Work } \\
\hline Current job $(n=70)$ & & & & $1.0 *$ \\
\hline No & $68(97)$ & $51(72.8)$ & $17(24.3)$ & \\
\hline Yes & $2(3)$ & $2(2.8)$ & 0 & \\
\hline Government benefit & & & & $0.02 *$ \\
\hline No & $45(64.3)$ & $30(42.8)$ & $15(21.4)$ & \\
\hline Yes & $25(35.7)$ & $23(32.8)$ & $2(2.8)$ & \\
\hline \multicolumn{5}{|l|}{ Substance use } \\
\hline Lifetime $(n=70)$ & & & & $1.0 *$ \\
\hline Alcohol & $11(15.7)$ & $8(11.5)$ & $3(4.3)$ & \\
\hline Alcohol + crack & $52(74.3)$ & $39(55.7)$ & $13(18.6)$ & \\
\hline Alcohol + cocaine & $7(10)$ & $6(8.6)$ & $1(1.4)$ & \\
\hline Last year $(n=70)$ & & & & $1.0 *$ \\
\hline No & $1(1.5)$ & $1(1.5)$ & 0 & \\
\hline Yes & $69(98.5)$ & $52(74.3)$ & $17(24.3)$ & \\
\hline Overdose $(n=70)$ & & & & $0.39 *$ \\
\hline No & $42(60)$ & $30(42.8)$ & $12(17.2)$ & \\
\hline Yes & $28(40)$ & $23(32.8)$ & $5(7.1)$ & \\
\hline
\end{tabular}

Data expressed as $\mathrm{n}(\%)$, unless otherwise specified.

$\mathrm{SD}=$ standard deviation.

* Fisher's exact test, ${ }^{+}$Student's $t$ test.

Of the 69 subjects, 35 (51\%) remained in the household until the end of treatment or were reinserted in society (formal jobs and return to the family) and 34 $(49 \%)$ had a recurrence during their stay; of the latter, $16(47 \%)$ volunteered for treatment at a therapeutic community or psychiatric clinic, $8(23.5 \%)$ chose to continue with outpatient treatment only, and 6 (29.5\%) returned to their families and continued treatment at a CAPS unit. At the time of data collection, $28(80 \%)$ of those who completed the program were employed in 
regular positions and 7 (20\%) received governmental support for permanent disability on medical or psychiatric grounds.

Twenty-nine of the 34 cases of recurrence occurred in the first 45 days of residence in the $\mathrm{RH}$, and five between 150 and 180 days of residence. The reason most frequently cited by subjects was the difficulty of establishing family ties and building a social support network. This issue was mentioned by $89.1 \%$ of the subjects.

A total of 1,283 urine toxicological tests were carried on 69 individuals during the 11-month observation period, resulting in 43 positive tests for cocaine or crack cocaine and 8 positive tests for THC (marijuana). The program conducted, on average, 36 tests for each subject, every five days, during their whole stay.

Of the 69 residents, seven had psychiatric comorbidities: four residents (three men, one woman) had schizophrenia; and three (one man, two women) had intellectual disability. Two other residents had acquired limb deformities. The most common drug use history was use of alcohol and cocaine (72\%), followed by alcohol use alone (16\%).

\section{Discussion}

In this study, we report the results of a retrospective analysis of the records of all subjects treated in the $\mathrm{RH}$ of the Restart Program since its creation, from June 2016 to May 2017. Our data suggest that RH can be an important factor of integrated care in Brazil, similarly to what is observed in several other countries. It appears to be effective as a treatment component of a postdetoxification program.

As expected, in our sample there were more men than women. Even though the rates of substance abuse among women are getting closer to those observed in men, women still drink less, but they get sick earlier and more severely. ${ }^{6-8}$ Differences between the two genders exist, with women presenting early physical changes due to the use of psychoactive substances that cause liver damage.9,10 The greater physical frailty may explain why the women in our sample were younger than the men and were already in the street and unemployed. In our sample, almost half of the women had already exchanged sex for drugs, unlike the male residents. These data are in agreement with the literature, and this behavior may increase the risk for sexually transmitted diseases and unwanted pregnancy. ${ }^{11}$ Another interesting fact of our research is that most of the residents asked for help by seeking health professionals, not family members. Horta et al. had already reported that family groups may be protective factors, but can also be an important risk factor for crack use, e.g., because of the shame and stigma that affects family relations. ${ }^{12}$ In Brazil, government benefits are more easily granted if the subject has worked formally. Virtually all $\mathrm{RH}$ residents were not working and therefore would not have the right to apply for the government benefit.

Detoxification is well-organized in the state of São Paulo, and performed by multiple services. However, as a stand-alone treatment, detoxification appears to be ineffective, with recurrence rates as high as $80 \%$ one month after discharge. ${ }^{13,14}$ The main reason for recurrence is premature return to an uncontrolled environment where the individual is exposed to cues that may precipitate relapse and recurrence, ${ }^{14}$ especially in the context of other vulnerabilities, such as homelessness and unemployment. ${ }^{15}$ Recent controlled studies have demonstrated that $\mathrm{RH}$ improves outcomes for substance users, ${ }^{4,16}$ with higher rates of drug abstinence relative to standard treatments. ${ }^{17-22}$ A clinical trial of the Johns Hopkins University School of Medicine $\mathrm{RH}$ program involving 83 participants was carried out. ${ }^{23}$ Urine samples were collected twice weekly and, in the event of a positive test, the participant was removed from the $\mathrm{RH}$, tested daily at a clinic and returned to the program upon submission of a drug-negative urine sample. The rate of drug abstinence after 30 days was $50 \%$ for subjects receiving reinforcement-based treatment in $\mathrm{RH}$ and $13 \%$ for subjects receiving standard care $(p<0.001)$. At six-month follow-up, $37 \%$ of the subjects who had received reinforcement-based treatment among $\mathrm{RH}$ participants remained abstinent compared with $20 \%$ of those who received standard care. The mean length of stay in $\mathrm{RH}$ was 49.5 days.

In addition, we had a high rate of employability during and after treatment at the $\mathrm{RH}$ program, corroborating previous studies that suggested positive results for similar supervised housing services. Figure 1 is a flow diagram explaining the process of admission and maintenance of treatment for all the subjects treated at our RH program. The program is structured to allow up to 180 days in $\mathrm{RH}$ and is thus considered a long-stay program. Long-stay programs are considered the best option for clients whose drug and alcohol use is long-term and rooted and who are likely to be socially excluded, unemployed, in severe housing need, lacking in life skills and facing legal problems. ${ }^{4}$ This population makes up the majority of our service users. ${ }^{1}$ Also, even if a resident resumes the use of crack, he is supported by the other services that compose the Restart Program, and will be reinserted in the $\mathrm{RH}$ program when meeting the eligibility criteria. 
To be eligible for the $\mathrm{RH}$ program, subjects must be undertaking regular outpatient treatment. The maximum length of stay in the program is 12 months. Upon admission to the $\mathrm{RH}$ program, the residents' papers are regularized and they are referred to a one-week work preparation program. A collaboration between the state and private companies provides job opportunities and is monitored by a social worker. Residents are also given the opportunity to return to education. The approach to family reintegration is determined on a case-by-case basis after evaluation of family ties. During the stay, urine samples are analyzed in order to encourage abstinence, but relapse and recurrence are not absolute criteria for exclusion from the program. Each case is analyzed by a multidisciplinary team and a decision about the best treatment option is made in conjunction with the patient.

Criticism of $\mathrm{RH}$ programs has focused on the use of urine analysis to detect relapse and recurrence. In recent years, controversy has developed over the use of urine, blood, saliva, and breath tests to provide evidence of drug use. ${ }^{24}$ Legal questions have already been raised about the validity of the test procedures, the reliability of the evidence obtained and the balance between the subjects' right to privacy and the need to monitor drug use. Even though laboratory methods are controversial, they seem to have a positive impact on adherence to treatment and maintenance of abstinence. ${ }^{24}$

These preliminary findings are consistent with evidence from other countries that suggest that $\mathrm{RH}$ programs are effective, but the limitations of the present study must be taken into account. This was a single-center, retrospective study lacking a standard-care comparison group. Nevertheless, the RH program on which we report represents the first of its kind in Brazil. A further limitation is the lack of post-discharge follow-up data that could show the long-term effectiveness of the program. For future perspectives, clinical trials evaluating the efficacy of the RH program are necessary for a better evaluation of its clinical use, as are cost-effectiveness analyses for the future development of public health policies. We

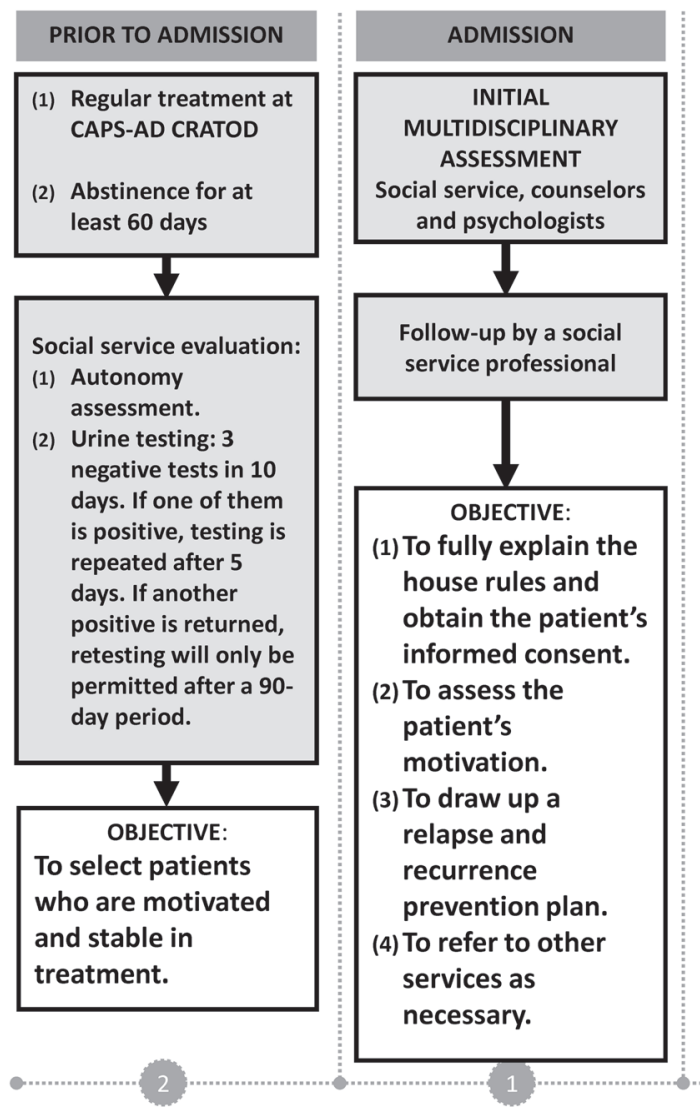

\begin{tabular}{|c|}
\hline THERAPEUTIC PLAN \\
\hline SUD COUNSELOR: \\
Follow-up by a social \\
assistant throughout \\
treatment \\
\hline \multicolumn{2}{|c|}{ STRATEGY: } \\
\hline $\begin{array}{l}\text { (1) Care in day-by-day } \\
\text { issues. } \\
\text { (2) Motivational } \\
\text { interview. } \\
\text { (3) Abstinence } \\
\text { maintenance and } \\
\text { testing. } \\
\text { (4) Self-care } \\
\text { promotion. } \\
\text { (5) Help overcome } \\
\text { social and } \\
\text { interpersonal } \\
\text { issues. } \\
\text { (6) Contingency } \\
\text { management. } \\
\text { (7) Group therapy. } \\
\text { (8) Social } \\
\text { reintegration. } \\
\text { (9) Mutual help. } \\
\text { (10) CAPS-AD CRATOD. }\end{array}$ \\
\hline
\end{tabular}

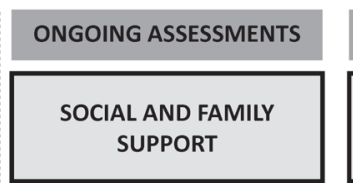

STRATEGY:
(1) Relapse prevention.

(2) Family groups -

determine the

person in charge of

the treatment.

(3) Refer relatives to

support groups.

(4) Follow-up of family

members.

(5) Refer to other

network services.

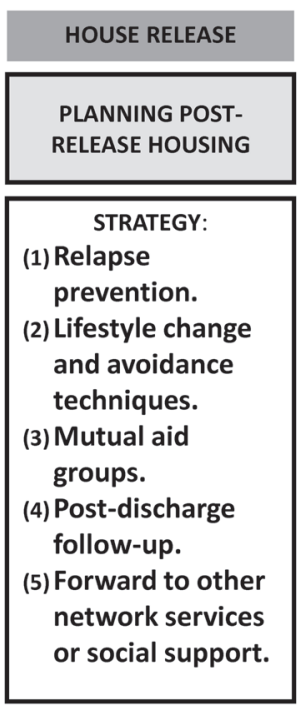

POSITIVE TEST DURING THE STAY: first time $=$ discussion of the case by the housing team and the CAPS-AD CRATOD; maintenance of the dweller $\mid$ recidivism = possible referrals: (1) emergency care, (2) shelter, (3) return to the family, or (4) therapeutic community.

Figure 1 - The recovery housing program flow diagram: eligibility criteria and treatment phases. CAPS-AD = Centro de Atenção Psicossocial - Álcool e Drogas; CRATOD = Centro de Referência de Álcool, Tabaco e Outras Drogas; SUD = substance use disorder. 
are currently implementing a prize-based contingency management treatment as part of the $\mathrm{RH}$ program, in order to enhance adherence to treatment and to training programs for a better insertion in the job market.

\section{Acknowledgments}

This study was financed in part by Coordenação de Aperfeiçoamento de Pessoal de Nível Superior (CAPES; finance code 001).

\section{Disclosure}

No conflicts of interest declared concerning the publication of this article.

\section{References}

1. Ribeiro $M$, Duailibi $S$, Frajzinger $R$, Alonso $A L$, Marchetti $L$, Williams AV, et al. The Brazilian "Cracolandia" open drug scene and the challenge of implementing a comprehensive and effective drug policy. Addiction. 2016;111:571-3.

2. Polcin DL, Korcha R, Bond J, Galloway G. Eighteen-month outcomes for clients receiving combined outpatient treatment and sober living houses. J Subst Use. 2010;15:352-66.

3. Best D, O'Grady A, Charalampous I, Gordon G. National needs assessment for tier 4 drug services in England. London: National Treatment Agency; 2006.

4. National Health Service, National Treatment Agency for Substance Misuse. Models of residential rehabilitation for drug and alcohol misusers. London: NHS - National Treatment Agency; 2006. p. 17-8.

5 Booth R. Alcohol halfway houses: treatment length and treatment outcome. Int J Addiction. 1981;16:927-34.

6. Davis S. Effects of chemical dependency in parenting women. In: Watson RR, editor. Addictive behaviors in women. New Jersey: Humana; 1994. p. 381-414.

7. Wolle CC, Sanches M, Zilberman ML, Caetano R, Zaleski M, Laranjeira RR, et al. Differences in drinking patterns between men and women in Brazil. Rev Bras Psiquiatr. 2011;33:367-73.

8. Zilberman M, Tavares H, el-Guebaly N. Gender differences and similarities: prevalence and course of alcohol and other substance related disorders. J Addict Dis. 2003;22:61-74.

9. Gigliotti A, Guimarães A. Dependência, compulsão e impulsividade. In: A mulher e a dependência química sob uma perspectiva feminina. Rio de Janeiro: Rubio; 2007. p. 19-30.
10. Kandall SR. Women and drug addiction: a historical perspective. J Addict Dis. 2010;29:117-26.

11. Ribeiro $M$, Laranjeira $R$, organizadores. O tratamento do usuário de crack. 2a ed. Porto Alegre: Artmed; 2012. p. 585-98.

12. Horta RL, Vieira LS, Balbinot AD, de Oliveira GO, Poletto $S$, Teixeira VA. Families and crack cocaine consumption. J Bras Psiquiatr. 2014;63:104-12.

13. Chutuape MA, Jasinski DR, Fingerhood MI, Stitzer ML. One, three-, and six-month outcomes after brief inpatient opioid detoxification. Am J Drug Alcohol Abuse. 2001;27:19-44.

14. Shaham Y, Shalev U, Lu L, De Wit H, Stewart J. The reinstatement model of drug relapse: history, methodology and major findings. Psychopharmacology (Berl). 2003;168:3-20.

15. Laudet $A B$, White $W$. What are your priorities right now? Identifying service needs across recovery stages to inform service development. J Subst Abuse Treat. 2010;38:51-9.

16. Laranjeira $\mathrm{R}$, Elbreder $\mathrm{M}$, Ribeiro $\mathrm{M}$. Moradia assistida para dependentes químicos. In: O tratamento do usuário de crack, avaliação clínica, psicossocial, neuropsicológica, e de risco. São Paulo: Casa Leitura Médica; 2010. p. 337-42.

17. Larimer ME, Malone DK, Garner MD, Atkins DC, Burlingham B, Lonczak HS, et al. Health care and public service use and costs before and after provision of housing for chronically homeless persons with severe alcohol problems. JAMA. 2009;301:134957.

18. Milby JB, Schumacher JE, Wallace D, Freedman MJ, Vuchinich RE. To house or not to house: the effects of providing housing to homeless substance abusers in treatment. Am J Public Health. 2005;95:1259-65.

19. Jason LA, Olson BD, Ferrari JR, Lo Sasso AT. Communal housing settings enhance substance abuse recovery. Am J Public Health. 2006;96:1727-9.

20. Jason LA, Davis MI, Ferrari JR. The need for substance abuse after-care: longitudinal analysis of Oxford House. Addict Behav. 2007;32:803-18.

21. Milby JB, Schumacher JE, McNamara C, Wallace D, Usdan S, McGill $T$, et al. Initiating abstinence in cocaine abusing dually diagnosed homeless persons. Drug Alcohol Depend. 2000;60:55-67.

22. Schumacher JE, Milby JB, Wallace D, Meehan D-C, Kertesz $S$, Vuchinich $R$, et al. Meta-analysis of day treatment and contingency-management dismantling research: Birmingham Homeless Cocaine Studies (1990-2006). J Consult Clin Psychol. 2007;75:823-8.

23 Tuten M, DeFulio A, Jones HE, Stitzer M. Abstinence-contingent recovery housing and reinforcement-based treatment following opioid detoxification. Addiction. 2012;107:973-82.

24. West LJ, Ackerman D. The drug-testing controversy. J Drug Issues. 1993;23:579-95.

\section{Correspondence:}

Ariadne Ribeiro

Centro de Referência em Álcool Tabaco e Outras Drogas (CRATOD), Secretaria Estadual de Saúde

Rua Prates, 165, Bom Retiro

01121-000 - São Paulo, SP, Brazil

Tel. : +55 (11) 33294455

E-mail: ariadnerf@gmail.com 